\title{
45. Light and Temperature Compensate Possibly for Chemical Conditions of Embryonic Development in the Silkworm Bombyx mori*)
}

\author{
By Masaru KaTo \\ Department of Zoology, Faculty of Science, Kyoto University \\ (Comm. by Eikiti Hiratsuka, M. J. A., March 12, 1973)
}

In the silkworm Bombyx mori, most investigation on the effects of light and/or temperature in the incubation period of embryonic development has been concentrated on the diapause formation of the egg. ${ }^{1)}$ On the other hand, in the studies of hatchability of the egg in the silkworm, attention has always been given to environmental conditions during winter storage of eggs..$^{2), 3)}$ Insofar as silkworms are reared on mulberry leaves, no investigation or results to date have shown any effect of nutrition on lowering hatchability of the silkworm.

In the present paper I would like to propose a remarkable relationship between the diapause mechanism and hatchability under special conditions, i.e., (i) photoperiod, (ii) temperature, (iii) food quality using an artificial diet under aseptic conditions.

Materials and methods. The experiments were carried out with a bivoltine race of silkworm, Bombyx mori ( $\mathrm{F}_{1}$ of the cross of races Gunko and Manri). The menu of the artificial diet in these experiments can be seen in our previous paper"); the so called "M-O" diet of Kato Laboratory, which contained no mulberry leaf powder or extracts whatsoever.

The schedules for the photoperiod, temperature, and incubation conditions of the embryo were $8 \mathrm{~L}-15^{\circ} \mathrm{C}$ ( 8 hours light and 16 hours dark at $15^{\circ} \mathrm{C}$ ) and $16 \mathrm{~L}-25^{\circ} \mathrm{C}$ ( 16 hours light and 8 hours dark at $25^{\circ} \mathrm{C}$ ), and $8 \mathrm{~L}-25^{\circ} \mathrm{C}, 16 \mathrm{~L}-25^{\circ} \mathrm{C}$, and $20 \mathrm{~L}-25^{\circ} \mathrm{C}$ for the larval stage respectively as can be seen in Table I. The nutritional conditions are also indicated in the Table.

Results and discussion. Most of the eggs which were incubated under the conditions of $8 \mathrm{~L}-15^{\circ} \mathrm{C}$ were found to produce moths laying non-diapause eggs regardless of day length; $8 \mathrm{~L}$ or $16 \mathrm{~L}$ in the larval stage insofar as they were reared on the M-O artificial diet under aseptic conditions proved the same. It was remarked that when nondiapause eggs reached the hatching stage they exhibited very poor hatchability. See Table I first line. This indicates that low levels of

*) Supported in part by a Research Grant, Environmental Control No. 92715. 
Table I. Schedule of environmental conditions of light, temperature and plus results

\begin{tabular}{c|c|c|c|c}
\hline $\begin{array}{c}\text { Incubation } \\
\text { conditions } \\
\text { of embryo } \\
\text { (photoperiod } \\
\text { and temp.) }\end{array}$ & $\begin{array}{c}\text { Rearing } \\
\text { conditions } \\
\text { of larvae } \\
\text { (photoperiod } \\
\text { and temp.) }\end{array}$ & $\begin{array}{c}\text { Food conditions } \\
\text { of larvae }\end{array}$ & $\begin{array}{c}\text { Results of diapause } \\
\text { formation (No. of } \\
\text { non-diapaused moth } \\
\text { /total moth) }\end{array}$ & $\begin{array}{c}\text { hatchability } \\
(\% \text { of ave. } \\
\text { (tigat of inves- }\end{array}$ \\
\hline $8 \mathrm{~L}-15^{\circ} \mathrm{C}$ & $16 \mathrm{~L}-25^{\circ} \mathrm{C}$ & $\mathrm{M}-0$ diet & $\begin{array}{c}\text { Non-diapause } \\
(33 / 33)\end{array}$ & $26.12(33)$ \\
\hline $8 \mathrm{~L}-15^{\circ} \mathrm{C}$ & $16 \mathrm{~L}-25^{\circ} \mathrm{C}$ & $\begin{array}{c}\text { Artificial diet with } \\
\text { mulberry leaf } \\
\text { powder for 7 days } \\
\text { in 5th instar }\end{array}$ & $\begin{array}{c}\text { Non-diapause } \\
(26 / 26)\end{array}$ & $92.76(26)$ \\
\hline $8 \mathrm{~L}-15^{\circ} \mathrm{C}$ & $16 \mathrm{~L}-25^{\circ} \mathrm{C}$ & $\begin{array}{c}\text { Artificial diet with } \\
\text { mulberry leaf } \\
\text { powder for 2 days } \\
\text { before spinning } \\
\text { in 5th instar }\end{array}$ & $\begin{array}{c}\text { Non-diapause } \\
(18 / 18)\end{array}$ & $90.17(18)$ \\
\hline $16 \mathrm{~L}-25^{\circ} \mathrm{C}$ & $20 \mathrm{~L}-25^{\circ} \mathrm{C}$ & M-0 diet & $\begin{array}{c}\text { Non-diapause } \\
(8 / 30)\end{array}$ & $95.14(8)$ \\
\hline $16 \mathrm{~L}-25^{\circ} \mathrm{C}$ & $8 \mathrm{~L}-25^{\circ} \mathrm{C}$ & M-0 diet & $\begin{array}{c}\text { Non-diapause } \\
(10 / 32)\end{array}$ & $89.75(10)$ \\
\hline
\end{tabular}

hatchability were due to the particular nutritional conditions i.e., with the use of the M-O artificial diet, since it was never observed to be true in the case of silkworms raised on a diet of mulberry leaves. Further, when the artificial diet was modified to contain $50 \%$ mulberry leaf powder and fed during the larval 5th instar for seven days then the hatchability increased dramatically from that of $26 \%$ to $92 \%$. See Table I, 2nd line.

This suggests that some chemicals contained in the mulberry leaf powder most probably played an important role in the acceleration of the embryonic development before hatching. What is more, it was found that these suggested chemical components, producing high percentage of hatchability, needed to be fed only two days prior to spinning of the cocoon, but not in the early larval development. It was established that the high hatchability of non-diapause eggs can be completely controlled artificially as can be seen in Table I, by controlling environmental conditions i.e., long day and high temperature; $16 \mathrm{~L}$ and $25^{\circ} \mathrm{C}$, instead of the addition of mulberry leaf powder to the M-O diet, during the incubation time of the embryo. Thus, the environmental factors could be changed to induce some syntheses or to modify some chemicals in the metabolic sequences in relation to embryonic development. This induces high hatchability as when mulberry leaf powder was added to the M-O diet as shown in 2nd and 3rd lines in Table I. 
In the case of incubation at $16 \mathrm{~L}-25^{\circ} \mathrm{C}$ during the embryonic stage, the silkworm fed on mulberry leaves usually only produce diapause eggs but there is a particular tendency to produce non-diapause eggs by a significant percentage of worms fed on $\mathrm{M}-\mathrm{O}$ artificial diet regardless of the conditions i.e., at $8 \mathrm{~L}-15^{\circ} \mathrm{C}$ or $16 \mathrm{~L}-25^{\circ} \mathrm{C}$ during the incubation time of the embryo. It is quite interesting to note the fine differences seen in these non-diapause eggs which resulted by mistake from the process of diapause formation which must have been caused by $16 \mathrm{~L}-25^{\circ} \mathrm{C}$ during the incubation time of the embryo. These were still different from normally produced non-diapause eggs, because, such eggs had high hatchability (see Table I lines four and five) even if they failed to be diapause eggs under suitable conditions $16 \mathrm{~L}-25^{\circ} \mathrm{C}$ in the embryonic stage. In the initial stages of my work it was found that a certain component of mulberry leaf powder was successful in producing high hatchability. This further suggests chemical studies to discover possible connecting mechanisms along with those effects of light and temperature.

Acknowledgement. The author expresses his appreciation to Drs. Y. Hamamura and S. Morohoshi for their kind advices, and Miss M. Yamanaka for her assistance.

\section{References}

1) Morohoshi, S.: Voltinism and internal secretion in the silkworm Bombyx mori. Kagaku, 28, 348 (1958).

2) Kawakita, K., and T. Ida: On the hatchability of the chilled hibernating eggs. Sum. of Kansai Anu. Meeting of J. S. S. J., p. 28 (1960).

3) Shimohata, S., and Hara, M.: Hatchability and embryonic development during the chilling time of hibernating eggs. Sum. of Tokai Anu. Meeting of J. S. S. J., p. 12 (1961).

4) Kato, M., and K. Sumimoto: Nutritional Studies on Excessive Larval Molting in the Silkworm Bombyx mori. Annotationes Zoologicae Japonenses, 41, 140 (1968). 